\title{
Stomach Contents of the Thorny Skate, Raja radiata, from the Northwest Atlantic
}

\author{
Wilfred Templeman \\ Department of Fisheries and Oceans, Fisheries Research Branch \\ Northwest Atlantic Fisheries Centre, P. O. Box 5667 \\ St. John's, Newfoundland, Canada A1C 5X1
}

\begin{abstract}
Stomach contents of thorny skates, Raja radiata, collected in the Northwest Atlantic from West Greenland to Georges Bank during 1947-67, were examined and measured by volume. The stomach contents consisted mostly of fish, followed by decapods (especially spider crabs and hermit crabs), cephalopods and polychaetes. The most numerous food items, in descending order of occurrence, were crabs, polychaetes, shrimp, sand lance, amphipods and capelin. The stomachs of smaller skates contained higher proportions of cephalopods, polychaetes and amphipods and lower proportions of fish species than the larger skates. Over $30 \%$ of the fish food was composed of fish and fish viscera, mainly cod and haddock, discarded from fishing vessels. The presence of whelks without shells in the stomachs indicates that this skate may be able to shake whelks out of their shells for food.
\end{abstract}

\section{Introduction}

Until the work of McEachran et al. (1976), which included food of the thorny skate in the southern part of its range in the western North Atlantic, only generalities, based on few specimens, were available on the food of this skate (Bigelow and Schroeder, 1953a). Studies on the food of other western Atlantic skates have been reported by Richards et al. (1963) for Raja erinacea, Fitz and Daiber (1963) for $R$. erinacea and Raja eglanteria, and McEachran et al. (1976) for $R$. erinacea, Raja ocellata and Raja senta. The food of various species of skates in the Northeast Atlantic has been reported by many researchers, including Steven (1930), Du Buit (1968), Holden and Tucker (1974) and Ajayi (1982).

\section{Materials and Methods}

Stomach contents of 446 thorny skates in the fresh condition, taken mainly in bottom otter-trawl by research vessels operating from the St. John's Biologi- cal Station but occasionally by commercial trawlers, were examined during 1947-67. Of these, 325 had food in their stomachs. These examinations were carried out, as time permitted, on specimens collected from nearly all parts of the Northwest Atlantic region, extending from West Greenland to Georges Bank, in conjunction with other studies on the thorny skate (Templeman, 1982). The examinations were carried out in the field and usually permitted classification of the food items only to species or groups readily recognizable by the author without further detailed investigation. Volumetric measurements of the different food items in the stomachs were made by displacement of water in a graduated cylinder.

The numbers of thorny skate stomachs containing food by length and depth ranges from the various NAFO divisions are listed in Table 1 . In view of the small amounts of many prey species, the greatly different numbers of skates in the length and depth ranges from the various parts of the large region under consideration, and distortions due to the usual impossibility of determining whether some of the species, especially

TABLE 1. Numbers of thorny skate stomachs containing food in samples from various areas of the Northwest Atlantic at different ranges of depth for two length ranges of skate.

\begin{tabular}{|c|c|c|c|c|c|c|c|}
\hline \multirow[b]{2}{*}{ Area } & \multirow{2}{*}{$\begin{array}{c}\text { NAFO } \\
\text { Divisions }\end{array}$} & \multicolumn{2}{|c|}{$17-200 m$} & \multicolumn{2}{|c|}{$201-400 \mathrm{~m}$} & \multicolumn{2}{|c|}{$401-740 \mathrm{~m}$} \\
\hline & & $21-60 \mathrm{~cm}$ & $61-102 \mathrm{~cm}$ & $21-60 \mathrm{~cm}$ & $61-102 \mathrm{~cm}$ & $21-60 \mathrm{~cm}$ & $61-102 \mathrm{~cm}$ \\
\hline West Greenland & $1 A B C D$ & - & - & 11 & - & 3 & - \\
\hline South Baffin Island & $\mathrm{OB}$ & - & - & 12 & - & 1 & - \\
\hline Ungava Bay & - & 1 & - & 7 & - & 2 & - \\
\hline Labrador & $2 \mathrm{HJ}$ & - & - & 4 & 1 & 2 & - \\
\hline East Newfoundland & $3 K L$ & 9 & 42 & 21 & 33 & 1 & 2 \\
\hline Flemish Cap & $3 \dot{M}$ & 1 & - & - & - & 1 & 2 \\
\hline Grand Bank-St. Pierre Bank & 3NOP & 13 & 110 & - & 33 & - & - \\
\hline Gulf of St. Lawrence & 4RST & 4 & - & - & - & - & - \\
\hline Scotian Shelf-Georges Bank & $4 V W+5 Z$ & 7 & - & 1 & 1 & - & - \\
\hline Total & & 35 & 152 & 56 & 68 & 10 & 4 \\
\hline
\end{tabular}


partly digested material, were taken directly as food or represented the stomach contents of the prey species, it was not considered worthwhile to present finer divisions of the data than those for two length ranges of skates from two depth ranges in the entire region. The skates were measured as total length from the tip of the snout to the tip of the tail.

\section{Results}

The food percentages in Table 2 are based on the total volumetric contents of stomachs containing food. Fish, including fish offal (17\%), made up $74 \%$ of the stomach contents, the most important food fishes being redfish, Sebastes sp. (18\%), haddock, Melanogrammus aeglefinus (14\%) and sand lance, Ammodytes sp. (12\%). Most of the fish offal was cod and haddock (16\%). Invertebrate food constituted $25 \%$ of the stomach contents, the most numerous groups being crabs (14\%), cephalopods $(5 \%)$, and polychaetes $(4 \%)$. Invertebrates were most numerous as food, with spider crabs and hermit crabs being found in 30 and $17 \%$ of the stomachs respectively, followed by polychaetes $(30 \%)$, shrimp (17\%) and amphipods $(12 \%)$. The most numerous fish species occurring as food were sand lance (14\%) and capelin (7\%).
The stomach contents of the smaller $(21-60 \mathrm{~cm})$ skates consisted of higher percentages of crabs (22\%), cephalopods $(20 \%)$, polychaetes $(11 \%)$ and amphipods $(4 \%)$ than the larger $(61-102 \mathrm{~cm})$ skates $(14,3,3$ and $0.1 \%$ respectively). These four groups of food items also occurred in higher percentages of the stomachs of smaller skates. Fish species were more important as food for the larger skates ( $78 \%$ by volume) than for the smaller skates ( $35 \%$ by volume), with the overall frequency of occurrence in the larger skates being more than twice that in the smaller ones. The larger skates fed on a much greater variety of fish species than the smaller skates, with sand lance being relatively important as food for each size group.

With respect to depth, fish (including offal) made up $69 \%$ of the total food volume in the stomachs of thorny skate from the 17-200 m depth range and $82 \%$ from the 201-700 $\mathrm{m}$ depth range, with haddock and sand lance being the most important food fishes at the shallower depths and redfish and sand lance at greater depths. Among the invertebrates, cephalopods were most important as food in deep water and crabs in shallow water. Polychaetes were commonly used as food and occurred in $30 \%$ of the stomachs in each depth range. The shrimp, Sergestes sp., and octopus

TABLE 2. Stomach contents of thorny skates in the Northwest Atlantic (from West Greenland to Georges Bank) in percentages of total stomach contents for each length and depth range. (Values in parentheses are percentages of presence of food item in stomachs containing food; these percentages are not additive because more than one type of food was found in a stomach.)

\begin{tabular}{|c|c|c|c|c|c|c|c|c|c|c|c|c|c|}
\hline \multirow{4}{*}{$\begin{array}{l}\frac{\text { Phylum }}{\text { Cnidaria }} \\
\text { Mollusca }\end{array}$} & \multirow{3}{*}{\multicolumn{2}{|c|}{$\frac{\text { Family }}{\text { Scyphozoa, Actiniaria }}$}} & \multicolumn{2}{|c|}{$17-200 m$} & \multicolumn{3}{|c|}{$201-740 \mathrm{~m}$} & \multicolumn{3}{|c|}{$21-102 \mathrm{~cm}$} & \multicolumn{3}{|c|}{$17-740 \mathrm{~m}$} \\
\hline & & & \multirow{2}{*}{$\frac{21-60 \mathrm{~cm}}{-}$} & $61-102 \mathrm{~cm}$ & $21-60 \mathrm{~cm}$ & \multicolumn{2}{|c|}{$61-102 \mathrm{~cm}$} & $17-200 m$ & \multicolumn{2}{|c|}{$201-740 \mathrm{~m}$} & \multirow{2}{*}{$\frac{21-60 \mathrm{~cm}}{-}$} & $61-102 \mathrm{~cm}$ & $21-102 \mathrm{~cm}$ \\
\hline & & & & $0.1 \quad(1)$ & - & 0.2 & (1) & 0.1 (1) & 0.2 & (1) & & $0.1 \quad(1)$ & $0.1 \quad(1)$ \\
\hline & Gastropoda & - Whelks (mainly) & - & $1.1(12)$ & - & - & & $1.1(10)$ & - & & - & $0.7 \quad(8)$ & $0.6 \quad(6)$ \\
\hline & Bivalvia & - Clams & - & $<0.1 \quad$ (2) & - & - & & $<0.1 \quad$ (2) & - & & - & $<0.1 \quad$ (1) & $<0.1 \quad$ (1) \\
\hline & Cephalopoda & - Gonatus tabricii & - & $<0.1 \quad$ (1) & $0.4 \quad(3)$ & $<0.1$ & (1) & $<0.1$ & 0.1 & (2) & $0.2 \quad(2)$ & $<0.1 \quad$ (1) & $<0.1 \quad$ (1) \\
\hline & & - lllex illecebrosus & 24.6 & - & - & 5.8 & (1) & 1.5 & 5.3 & (1) & $11.0 \quad(1)$ & $2.4(0.4)$ & $3.1 \quad(1)$ \\
\hline & & - Squid and octopus & - & $<0.1 \quad$ (1) & $16.6(0.4)$ & 2.2 & (3) & $<0.1 \quad(1)$ & 3.6 & (6) & $9.2 \quad(6)$ & $0.9 \quad(2)$ & $1.6 \quad(3)$ \\
\hline Annelida & Polychaeta & $\cdots$ & $14.3(51)$ & $4.0(26)$ & 7.6 (38) & 1.81 & (22) & $4.6(30)$ & 2.4 & (30) & $10.6(43)$ & 3.1 (25) & $3.7(30)$ \\
\hline \multirow{16}{*}{$\begin{array}{l}\text { Arthropoda } \\
\text { (Crustacea) }\end{array}$} & Cumacea & $\cdots$ & - & - & $0.2 \quad(2)$ & $<0.1$ & (1) & - & $<0.1$ & (1) & $0.1 \quad(1)$ & $<0.1(0.4)$ & $<0.1 \quad$ (1) \\
\hline & Isopoda & $\cdots$ & 0.5 & - & - & $<0.1$ & (3) & $<0.1 \quad$ (1) & $<0.1$ & (1) & $0.2 \quad(1)$ & $<0.1 \quad(1)$ & $<0.1 \quad$ (1) \\
\hline & Amphipoda & - Bottom types (mainly) & $4.0(40)$ & $0.1 \quad(7)$ & $3.6(21)$ & - & & $0.3(13)$ & 0.4 & (10) & $3.8(28)$ & $0.1 \quad(4)$ & $0.3(12)$ \\
\hline & Mysidacea & $\cdots$ & $<0.1 \quad$ (3) & - & $0.2 \quad(2)$ & - & & $<0.1$ & $<0.1$ & (1) & 0.1 & - & $<0.1 \quad$ (1) \\
\hline & Euphausiacea & $\cdots$ & - & - & $1.5(11)$ & $<0.1$ & (3) & - & 0.2 & (7) & 0.8 & $<0.1 \quad(1)$ & $0.1 \quad(3)$ \\
\hline & Decapoda & - Argis dentata & 6.3 & - & - & - & & 0.4 & - & & 2.8 & - & $0.2 \quad(1)$ \\
\hline & (Natantia) & - Pandalus sp. & - & - & $3.1 \quad(8)$ & 0.1 & (3) & - & 0.4 & $(5)$ & 1.7 & $<0.1 \quad$ (1) & $0.2 \quad(2)$ \\
\hline & & - Sergestes sp. & - & - & $0.3 \quad(2)$ & - & & - & $<0.1$ & (1) & 0.2 & - & $<0.1(0.3)$ \\
\hline & & - Spirontocaris sp. & - & $<0.1 \quad$ (1) & - & - & & $<0.1(0.4)$ & - & & - & $<0.1(0.4)$ & $<0.1(0.3)$ \\
\hline & & - Unidentified shrimp & $0.7 \quad(6)$ & $0.1 \quad(7)$ & $2.1(17)$ & 0.7 & (25) & $0.1 \quad(6)$ & 0.8 & (21) & $1.5(13)$ & $0.3(13)$ & $0.4(13)$ \\
\hline & Decapoda & -Pagurus krфyeri & $3.8 \quad(3)$ & $0.4 \quad(3)$ & - & - & & $0.6 \quad(3)$ & - & & $1.7 \quad(1)$ & $0.2 \quad(2)$ & $0.3 \quad(2)$ \\
\hline & (Anomura) & - Hermit crabs & $10.0(26)$ & $3.2(22)$ & $2.7 \quad(6)$ & 0.5 & $(4)$ & $3.6(22)$ & 0.7 & (5) & $6.0(13)$ & $2.1(16)$ & $2.4(15)$ \\
\hline & Decapoda & - Chionoecetes opilio & - & $3.0 \quad(9)$ & 0.1 & 0.7 & (3) & 2.9 & 0.6 & (2) & 0.1 & $2.0 \quad(7)$ & 1.9 \\
\hline & (Brachyura) & - Hyas araneus & - & $4.6 \quad(3)$ & - & - & & 4.3 & - & & - & 2.7 & 2.5 \\
\hline & & - Hyas coarctatus & $0.6 \quad(3)$ & - & - & - & & $<0.1 \quad$ (1) & - & & $0.3 \quad(1)$ & - & $<0.1(0.3)$ \\
\hline & & - Unidentified spider crabs & $21.1(43)$ & $9.6(28)$ & $8.5(11)$ & 2.31 & (19) & $10.3(30)$ & 2.9 & (15) & $14.1(22)$ & $6.6(25)$ & $7.1(24)$ \\
\hline \multirow[t]{2}{*}{ Echinodermata } & Holothuroidea & - Sea cucumbers & - & $0.1 \quad(1)$ & $<0.1 \quad$ (2) & - & & 0.1 & $<0.1$ & $(1)$ & $<0.1$ & $0.1(0.4)$ & 0.1 \\
\hline & Ophiuroidea & - Brittle stars & - & $<0.1 \quad$ (1) & $0.1 \quad(2)$ & $<0.1$ & (1) & $<0.1 \quad$ (1) & $<0.1$ & $(1)$ & $0.1 \quad(1)$ & $<0.1 \quad$ (1) & $<0.1$ \\
\hline \multicolumn{3}{|c|}{ Unidentified invertebrate material } & - & $<0.1 \quad$ (1) & $0.2 \quad(2)$ & 0.1 & (1) & $<0.1 \quad$ (1) & 0.1 & $(1)$ & $0.1 \quad(1)$ & $<0.1 \quad$ (1) & $<0.1$ \\
\hline \multicolumn{3}{|c|}{ Total Invertebrates } & 86.0 & 26.4 & 47.4 & 14.4 & & 29.9 & 17.6 & & 64.7 & 21.4 & 24.7 \\
\hline
\end{tabular}




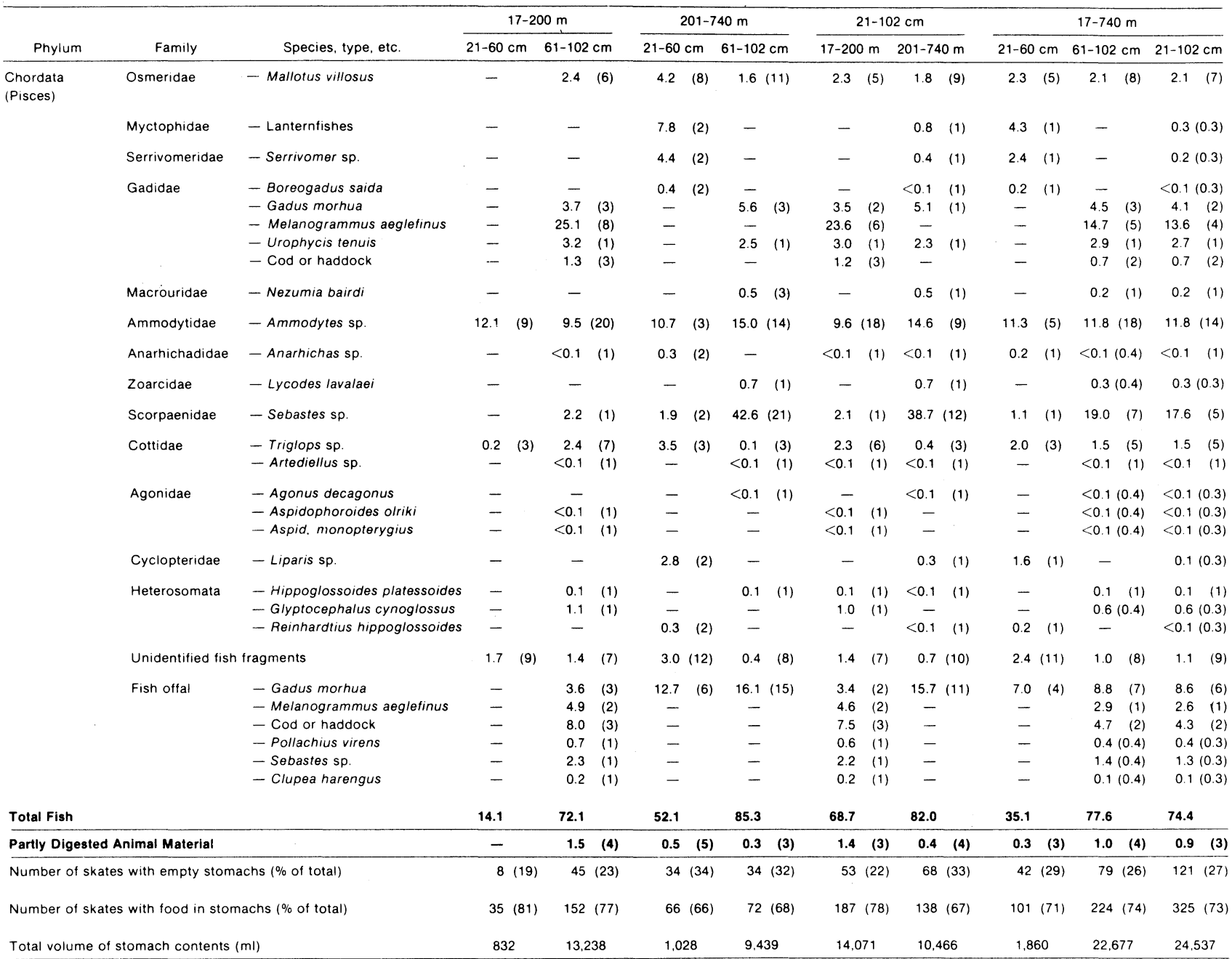

were found only in the stomachs of skates from depths greater than $400 \mathrm{~m}$.

Some of the prey species are usually found only in the northern and southern part of the region; for example, Gonatus fabricii occurs only from the Grand Bank northward and Illex illecebrosus from eastern Newfoundland southward. Haddock are most common from the southern Grand Bank and St. Pierre Bank southward to Georges Bank. The large quantities of haddock, cod and white hake and the offal of haddock, pollock, white hake and redfish were recorded mainly from the stomachs of thorny skates captured on Grand Bank and St. Pierre Bank. Typically, large quantities of these food items were recorded from relatively few large skates; for example, $90 \%$ of the volume of haddock in the stomachs came from nine large skates in a sample collected in April 1953 from the southwestern Grand Bank. The following observations were noted when these skates were examined: "The stomachs very often contained haddock of the size very common on the Grand Bank, mostly $32-36 \mathrm{~cm}$ long. These haddock in the skate stomachs were usual!y in excellent shape and were either picked up as discards from the trawlers or were obtained in the otter trawl."

In 10 skate stomachs containing whelks without shells, a total volume of $116 \mathrm{ml}$ of whelks was noted, whereas only $15 \mathrm{ml}$ of whelks in their shells were found in a total of three stomachs. Hermit crabs which live in whelk shells were occasionally noted in the skate stomachs without their protective whelk shells.

\section{Discussion}

For thorny skates, $R$. radiata, from the southern part of the Northwest Atlantic region (southern Scotian Shelf to Cape Hatteras), McEachran et al. (1976) found that fishes constituted $50 \%$ of the food volume and occurred in $25 \%$ of the stomachs. The higher percentages of fish ( $75 \%$ by volume in $50 \%$ of the stomachs) 
found in the present analysis were due partly to the relatively greater number of large skates $169 \%$ in the 61-102 cm length range) and partly to extensive feeding on cod and haddock viscera and on small haddock, large amounts of which were discarded by commercial trawlers fishing on Grand Bank and St. Pierre Bank (Templeman et al., 1978; Templeman and Bishop, 1979). Similarly, Tyler (1972) reported that fish made up a higher proportion of the diet of large $R$. radiata (40-65 cm long) than of smaller ones $(15-39 \mathrm{~cm})$. McEachran et al. (1976) reported that fish was a major component of the diet of $R$. radiata and $R$. ocellata longer than $70 \mathrm{~cm}$ in the southern part of the Northwest Atlantic, the volume of fish in the stomachs of the latter species increasing rapidly to $70 \%$ in $80-89 \mathrm{~cm}$ fish and to $80 \%$ in $90-99 \mathrm{~cm}$ fish. Similarly, Steven (1932), Du Buit (1968), Holden and Tucker (1974) and Ajayi (1982) noted, for a number of European species of Raja, an increasing proportion of fish in the stomachs with increase in size of the skates. McEachran et al. (1976) also showed that, for sympatric pairs of western North Atlantic skates, fish was more important as food in the larger species, $R$. ocellata and $R$. radiata, than in smaller members of the pairs, $R$. erinacea and $R$. senta. Templeman (1973) found that fish was greatly predominant as food in $95-170 \mathrm{~cm}$ specimens of the large deepwater skate, Bathyraja richardsoni.

Sand lance, Ammodytes sp., fairly important in the food of $R$. radiata in this paper $(12 \%$ by volume in $14 \%$ of the stomachs), was the most important fish prey of R. ocellata (McEachran et al., 1976). Sand lance typically burrow into the sand (Goode, 1884; Bigelow and Schroeder, 1953b) and skates may capture them while foraging over sandy bottom.

The importance of crabs and polychaetes as food items in the stomach samples reported here and the greater importance of amphipods in smaller than in larger thorny skates are similar to the observations by McEachran et al. (1976) for $R$. radiata. However, the proportions by volume of these invertebrates in the stomachs are probably artifically low, because many of the thorny skates taken off Newfoundland fed mainly on a variety of fish species which were abundant in the area at the time of sampling, in contrast to the present situation where haddock are very scarce on Grand Bank and St. Pierre Bank and the cod stocks are much less abundant than previously.

The observed presence in the skate stomachs of quantities of whelks mostly without shells and of some hermit crabs without the whelk shells in which they live agrees with the observations of Brightwell (1953), who reported that fragments of whelks, sometimes large portions, were found in the stomachs of the dogfish, Scyliorhinus canicula, but never any whelk shells. He noted, from aquarium observations, that the dogfish caught the expanded head and foot of a whelk in its jaws and shook it out of its shell and that hermit crabs were extracted from their shells in the same way.

\section{Acknowledgements}

I am grateful for the assistance of E. M. LeGrow in gathering the data and I thank S. H. Lee and J. V. Arklie for help in assembling the data.

\section{References}

AJAYI, T. O. 1982. Food and feeding habits of Raja species (Batoidei) in Carmarthen Bay, Bristol Channel. J. Mar. Biol. Assoc. U. K., 62 : 215-223

BIGELOW, H. B., and W. C. SCHROEDER. 1953a. Fishes of the western North Atlantic: sawfishes, guitarfishes, skates and rays. Mem. Sears Fdn. Mar. Res., 1(2), $514 p$.

1953b. Fishes of the Gulf of Maine. Fish. Bull., U. S., 53, 577 p.

BRIGHTWELL, L. R. 1953. Further notes on the hermit crab, Eupagurus bernhardus, and associated animals. Proc. Zool. Soc. Lond., 123: $61-64$

DU BUIT, M. H. 1968. Alimentation de quelques Rajides. Bull. Soc. Sci. Bretagne, 43: 305-314.

FITZ, E. S., and F. C. DAIBER. 1963. An introduction to the biology of Raja eglanteria Bose 1802 and Raja erinacea Mitchill 1825 as they occur in Delaware Bay. Bull. Bingham Oceanogr. Coll., 18(3): 69-97.

GOODE, G. B. 1884. The food fishes of the United States. Part 3, p. 163-682 in Section 1, Natural history of useful aquatic animals. Fish. Bull., U. S.., 895 p.

HOLDEN, M. J., and R. N. TUCKER. 1974. The food of Raja clavata Linnaeus 1758, Raja montagui Fowler 1910, Raja naevus Müller and Henle 1841 and Raja brachyura Lafont 1873 in British waters. ICES J. Cons., 35: 189-193.

MCEACHRAN, J. D., D. F. BOESCH, and J. A. MUSICK. 1976. Food division within two sympatric species-pairs of skates (Pisces, Rajidae). Mar. Biol., 35: 301-317

RICHARDS, S. H., D. MERRIMAN, and L. H. CALHOUN. 1963. Studies on the marine resources of southern New England. IX. The biology of the little skate, Raja erinacea Mitchill. Bull. Bingham Oceanogr. Coll., 18(3): 4-67.

STEVEN, G. A. 1930. Bottom fauna and the food of fishes. J. Mar. Biol. Assoc. U. K., 16: 677-706.

1932. Rays and skates of Devon and Cornwall. II. A study of the fishery, with notes on the occurrence, migration and habitats of the species. J. Mar. Biol. Assoc. U. K., 18: 1-33.

TEMPLEMAN, W. 1973. First records, description, and notes on the biology of Bathyraja richardsoni (Garrick) from the Northwest Atlantic. J. Fish. Res. Bd. Canada, 30; 1831-1840.

1982. Development, occurrence and characteristics of egg capsules of the thorny skate, Raja radiata. J. Northw. Atl. Fish. Sci. 3: 47-56.

TEMPLEMAN, W., V. M. HODDER, and R. WELLS. 1978. Age, growth year-class strength and mortality of the haddock, Melanogrammus aeglefinus, on the southern Grand Bank and their relation to the haddock fishery of this area. ICNAF Res. Bull., 13: 31-52.

TEMPLEMAN, W., and C. A. BISHOP. 1979. Age, growth, year-class strength and mortality of haddock, Melanogrammus aeglefinus, on St. Pierre Bank in 1948-75 and their relations to the haddock fishery of this area. ICNAF Res. Bull., 14: 85-99.

TYLER, A. V. 1972. Food resource division among northern, marine, demersal fishes. J. Fish. Res. Bd. Canada, 29: 997-1003. 